\title{
Economic Appraisal of Kinnow Production and its Marketing in Sirsa District of Haryana, India
}

\author{
Nirmal Kumar ${ }^{1}$, Anju Duhan ${ }^{2 *}$, Jitender Bhatia ${ }^{3}$ and Vinod Malik ${ }^{4}$ \\ ${ }^{1}$ District Extension Specialist (Agricultural Economics), KVK, Sirsa, India \\ ${ }^{2}$ HSB, GJUS \& T Hisar, Haryana, India \\ ${ }^{3}$ Department of Agricultural Economics, India \\ ${ }^{4}$ District Extension Specialist (Plant Pathology), KVK, Sirsa, India \\ *Corresponding author
}

\begin{tabular}{|c|c|}
\hline \multicolumn{2}{|r|}{ A B S T RA C T } \\
\hline & \multirow{5}{*}{$\begin{array}{l}\text { An economic analysis of kinnow has been presented through studying their costs and } \\
\text { returns. The average first year establishment costs per hectare for kinnow has been worked } \\
\text { out to be Rs. } 399466 \text {. The overall per hectare per year returns from kinnow orchards have } \\
\text { been worked out to be Rs. } 125478 \text {. The overall economic viability of the kinnow fruit, } \\
\text { mainly net present value, internal rate of return, benefit-cost ratio and payback period have } \\
\text { been computed as Rs. } 261258,15.57 \text { per cent, } 2.19 \text { and } 7.6 \text { years, respectively. The } \\
\text { average per quintal marketing cost at producers' level has been found to vary to the extent } \\
\text { of Rs. } 1120 \text {, Rs. } 1120 \text {, Rs. } 1195.83 \text { and Rs. } 1215.61 \text { for channels -I, II, III and IV, } \\
\text { respectively. The average per quintal marketing cost borne by the commission /wholesaler } \\
\text { in channel -I was Rs. } 660.58 \text {, whereas as it was Rs. } 620.92 \text {, Rs. } 532.48 \text { and Rs. } 252.39 \text { in } \\
\text { channels II, III and IV, respectively at the retailer's level and in channel-IV, whole of the } \\
\text { marketing cost was borne by the producer as there was direct marketing of produce. A } \\
\text { comparison of price spread through different marketing channels has revealed that } \\
\text { producers' share in consumers' rupee was the highest (about } 82.21 \% \text { ) in channel-IV, due } \\
\text { to self-sale in the local market. The marketing efficiency has been found to be highest in } \\
\text { channel-IV. The producer got maximum benefits in channel-IV, therefore this channel } \\
\text { should be followed to make producer highest beneficiary; although this channel has its } \\
\text { own limitations. }\end{array}$} \\
\hline $\begin{array}{l}\text { Kinnow production, } \\
\text { Marketing, Margin, } \\
\text { Cost, Channel and } \\
\text { Economic analysis of } \\
\text { kinnow. }\end{array}$ & \\
\hline Article Info & \\
\hline & \\
\hline & \\
\hline
\end{tabular}

\section{Introduction}

Horticultural sector play a vital role in providing the livelihood security to the farmers under the changing agriculture scenario. The diversification in agriculture for improving sustainability, profitability and productivity will help in not only improving the farm income but also will generate gainful employment. India is the world's second largest producer of fruits (57.73 million tons) with its projected value touching 98 MT by the year 2020-2021 (Banerjee, 2009), whereas for vegetables, India's diverse climate ensures availability of all varieties of fresh fruits and vegetables. It ranks second in fruits and vegetables production in the world, after China. As per National Horticulture Database published by National Horticulture Board, during 2014-15 India produced 86.602 million metric tons of fruits and 169.48 million metric tons of vegetables. The area 
under cultivation of fruits stood at 6.11 million hectares while vegetables were cultivated at 9.54 million hectares. The vast production base offers India tremendous opportunities for export. During 2015-16, India exported fruits and vegetables worth Rs. $8,391.41$ crores which comprised of fruits worth Rs. 3,524.50 crores and vegetables worth Rs. 4,866.91 crores (Anonymous, 2015-16). In Haryana, during the year 201516 Sirsa district ranked at the top with 9.65 thousand hectares $(49.15 \%)$ of area and 191.78 thousand tones $(63.55 \%)$ of production of total citrus cultivation in the state. In Sirsa, mostly Kinnow (Citrus nobilis $\mathrm{X}$ Citrus deliciosa) species of mandarin (Santra) and malta species of sweet orange are being grown among citrus fruits. Therefore, there is a need to boost its production as well as expand its area, which is possible only when a detailed cost and marketing analysis is carried out systematically.

Therefore, this study was undertaken with the following objective; (1) to study the cost and net returns from kinnow production, (ii) to find out its economic viability and (iii) to study marketing channel, marketing cost, price spread and marketing efficiency of Kinnow production in the Sirsa district of Haryana.

\section{Materials and Methods}

The present study was conducted in Sirsa district of Haryana state taking into account share of production and acreage of kinnow. Two blocks out of the district and three villages from each block were selected for the extraction of information from 60 farmers for the year 2015-16.

The growers were divided into three groups viz. small (0.01 - 2.00 ha), medium (2.01$4.00 \mathrm{ha}$ ) and large (above $4.01 \mathrm{ha}$ ). The data were collected on payments paid by growers for purchase of various inputs, resources employed, establishment of orchard and cultivation of crop and income received as well as costs involved in marketing of kinnow produce.

The economic viability of an enterprise like kinnow orchard was estimated by employing statistical tools like net present value (NPV), pay-back period, internal rate of return (IRR) and benefit cost ratio (BCR).

The information on marketing aspects of kinnow produce was analysed by computing marketing cost, margins, price spread and the marketing efficiency. The modified formulae were used for separating the 'post-harvest losses during marketing at different stages of marketing as well as for estimating the producers' share, marketing margins and marketing losses.

\section{Growers' net price}

The net price received by the grower was estimated as expressed in Equation (1):

$\mathrm{NPF}=\{\mathrm{GPF}\}-\{\mathrm{CF}\}-\{\mathrm{LF} \times \mathrm{GPF}\} \quad \ldots(1)$

Where, NPF is the net price received by the farmers (Rs./kg), GPF is the gross price received by the farmers or wholesale price to farmers (Rs. $/ \mathrm{kg}$ ), CF is the cost incurred by the farmers during marketing ( $\mathrm{Rs} / \mathrm{kg}$ ), and LF is the physical loss in produce from harvest till it reaches assembly market (per $\mathrm{kg}$ ).

\section{Marketing margins}

The margins of market intermediary included their profit, which accrued to him for storage, interest on capital and establishment after adjusting for the marketing loss during handling of produce. The general expression for estimating the margin for intermediary is given by equation (2): 
Intermediary margin $=$ Gross price (sale price) - Price paid (cost price) - Cost of marketing - Loss in value during handling (2)

Thus, the total marketing margin of the market intermediary (MM) was calculated as per equation (3):

$\mathrm{MM}=\mathrm{MMW}+\mathrm{MMR}$

Similarly, the total marketing cost (MC) incurred by the producer/ seller and by various intermediaries was calculated by equation (4):

$\mathrm{MC}=\mathrm{CF}+\mathrm{CW}+\mathrm{CR}$

Total loss in the value of produce due to injury/ damage caused during handling of produce from the point of harvest till it reached the consumers was estimated as per Equation (5):

$\mathrm{ML}=\{\mathrm{LF} \times \mathrm{GPF}\}+\{\mathrm{LW} \times \mathrm{GPW}\}+\{\mathrm{LR} \times$ GPR $\}$ (5)

\section{Marketing efficiency}

Modified marketing efficiency (ME) formula as defined by Acharya and Agarwal (2001) is given below:

$$
\mathrm{ME}=\frac{\mathrm{NPF}}{\mathrm{MM}+\mathrm{MC}+\mathrm{ML}}
$$

Where, NPF is net price received by the farmers (Rs. / $\mathrm{kg}$ ), $\mathrm{MM}$ is the marketing margin, $\mathrm{MC}$ is the marketing cost, and ML is the marketing loss.

\section{Results and Discussion}

\section{Cost analysis}

The establishment cost included expenditure on preparation of land, digging, filling and planting, planting material, purchase of essential input, etc. The operational cost included human labour cost, investment on nutrients (manures + fertilizers), expenditure on plant protection chemicals, irrigation charges, training/ pruning charges, permanent fencing, pond cost and land rent etc. Maintenance cost of orchards was obtained by using the quantity of inputs used per plant. The returns from kinnow orchard start from fifth year and it will be continued beyond 28 years, unlike Nagpur (oranges) manadarins. The total first year establishment costs on kinnow plantation (Table 1), revealed that costs of digging and filling and planting material was Rs. 5500 and Rs. 6764/h respectively in over all category.

The expenditure on construction of pond, installation of drip irrigation, payment for land leased in and permanent fencing of field was $(71.35 \%, 11.80 \%, 7.75 \%$ and $2.33 \% / \mathrm{ha})$ respectively. This indicates that the first year establishment cost increased with increase in the size of holding possibly due to more application of fertilizers and plant protection chemicals. These results are in conformity with the findings of Gangwar et al., (2005) and Bhat et al., (2011).

The year wise establishment incurred upto first four years in kinnow establishment (Table 2) revealed that establishment cost was maximum for all the size groups during the first year and in the successive years (upto plant started bearing); it was 40-50 per cent of the first year cost. The cost in the second year and onwards was low as expenditure incurred only on purchase of some inputs and maintenance of orchard.

The total establishment cost incurred on orchards was Rs 249469/ha in small, Rs 256421/ha in medium and Rs 258406/ha in large orchards. The average cost of four years was Rs.254285/ha. These results are line with the finding of Bhat et al., (2011). 
The item-wise operational cost of kinnow cultivation on per hectare basis (Table 3) indicated that overall expenditure incurred on nutrients was Rs. 15248 (38.55\%), indicating that it increased with increase in size of land holding. Whereas, inter-cultural operation and hoeing (Rs.7779), insecticides and fungicides (Rs.6359), showed decreasing trend with increasing size of farms.

The other costs involved in maintenance of kinnow orchard were pruning and cutting $(10.81 \%)$ and watch and ward $(5.80 \%)$. The total operational costs increased with the increase in the size of land holding.

\section{Gross returns and net profits}

The per hectare returns from kinnow orchards (Table 4) were highest in large size of holdings (Rs.132605), followed by medium (Rs.128389), small (Rs. 117862) orchards with an overall return Rs.125478. The similar pattern also existed in case net returns of kinnow cultivation.

The per hectare returns from kinnow orchard (Table 4) were highest in large size of holding (Rs.132605), followed by medium (Rs.128389), small (Rs. 117862) with an overall returns of (Rs.125478). The similar pattern also existed in case net returns of kinnow cultivation. It indicated that larger the size of an orchard, higher would b ethe returns which implies economics of scale of production. The similar findings had also reported by Thakur et al., (1986) and Sudha and Reddy (1988).

\section{Economics of kinnow production}

Table 5 reveals benefit-cost ratio (B-C ratio), net present value (NPV), pay-back period and internal rate of return (IRR) of orchards. In this study the NPV and B-C ratio have been calculated at 12 per cent discount rates.

\section{Marketing channels}

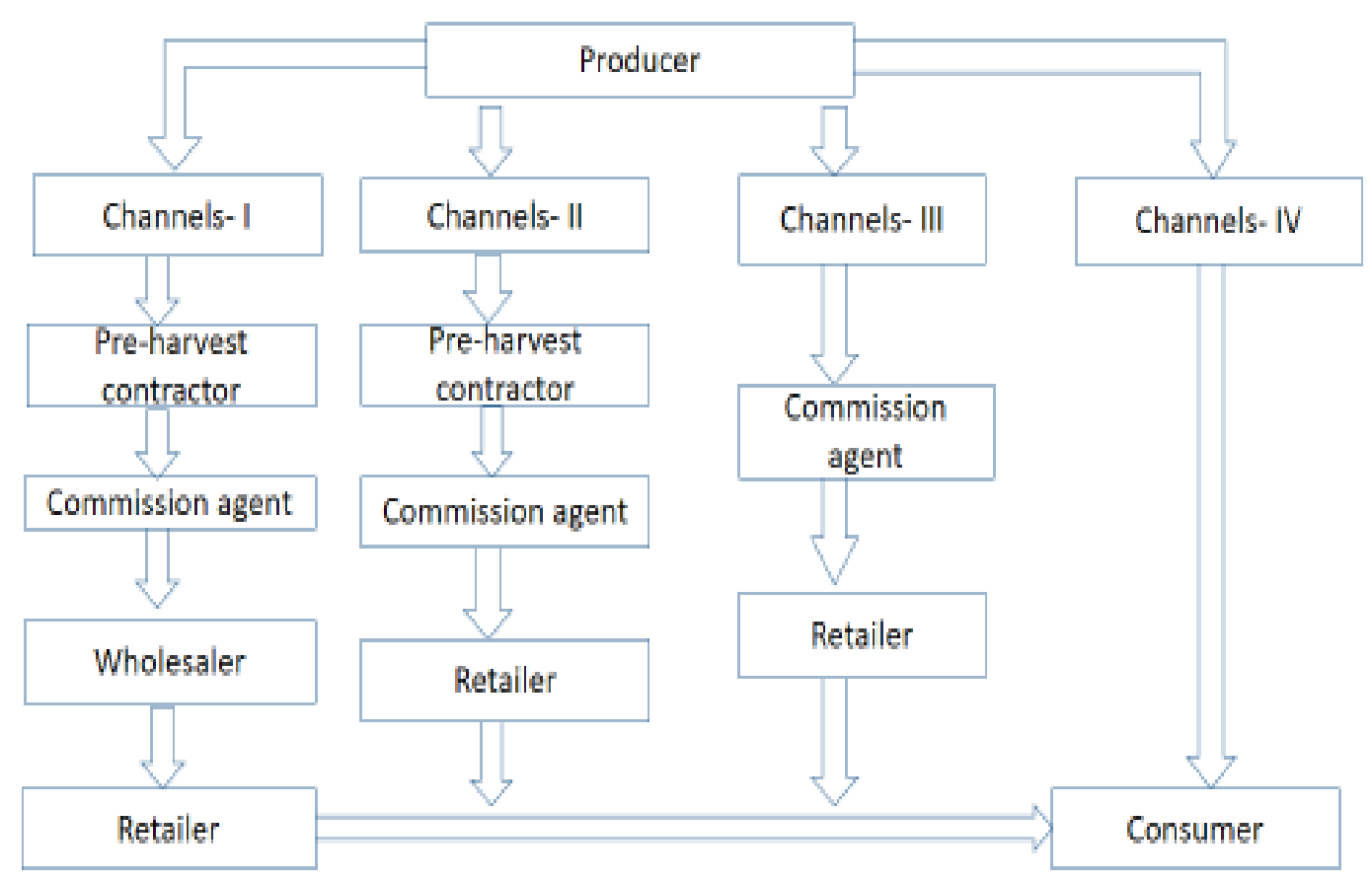


Table.1 Operation- wise first year establishment cost of kinnow on different size groups of kinnow orchards

\begin{tabular}{|l|c|c|c|c|}
\hline \multicolumn{1}{|c|}{ Particulars } & Small & Medium & Large & Overall \\
\hline Preparation of land and layout & 3260 & 3321 & 3367 & 3310 \\
& $(0.82)$ & $(0.83)$ & $(0.84)$ & $(0.83)$ \\
\hline Digging and filling of pits & 5500 & 5500 & 5500 & 5500 \\
& $(1.38)$ & $(1.37)$ & $(1.37)$ & $(1.38)$ \\
\hline Cost of filling & 3145 & 3156 & 3165 & 3154 \\
& $(0.79)$ & $(0.79)$ & $(0.79)$ & $(0.79)$ \\
\hline Cost of planting material & 6875 & 6760 & 6610 & 6764 \\
& $(1.73)$ & $(1.67)$ & $(1.65)$ & $(1.69)$ \\
\hline Planting cost & 1375 & 1380 & 1382 & 1379 \\
& $(0.35)$ & $(0.34)$ & $(0.34)$ & $(0.35)$ \\
\hline Training/pruning & 2750 & 2780 & 2798 & 2773 \\
& $(0.69)$ & $(0.69)$ & $(0.70)$ & $(0.69)$ \\
\hline Cost of drip establishment & 46250 & 47500 & 48000 & 47154 \\
& $(11.64)$ & $(11.86)$ & $(11.97)$ & $(11.80)$ \\
\hline Permanent fencing & 9250 & 9280 & 9364 & 9291 \\
& $(2.33)$ & $(2.35)$ & $(2.33)$ & $(2.33)$ \\
\hline Cost of tool \& implements & 2810 & 2895 & 2987 & 2887 \\
& $(0.71)$ & $(0.72)$ & $(0.74)$ & $(0.72)$ \\
\hline Cost of pond construction & 285000 & 285000 & 285000 & 285000 \\
& $(71.70)$ & $(71.18)$ & $(71.06)$ & $(71.35)$ \\
\hline Rental value of land & 30000 & 31525 & 31665 & 30978 \\
& $(7.55)$ & $(7.87)$ & $(7.89)$ & $(7.75)$ \\
\hline Miscellaneous & 1250 & 1310 & 1270 & 1276 \\
& $(0.31)$ & $(0.33)$ & $(0.32)$ & $(0.32)$ \\
\hline Total & $\mathbf{3 9 7 4 6 5}$ & $\mathbf{4 0 0 4 0 7}$ & $\mathbf{4 0 1 1 0 8}$ & $\mathbf{3 9 9 4 6 6}$ \\
& $(\mathbf{1 0 0 )}$ & $(\mathbf{1 0 0 )}$ & $(\mathbf{1 0 0 )}$ & $(\mathbf{1 0 0 )}$ \\
\hline
\end{tabular}

Table.2 Year wise establishment cost of Kinnow orchards on different size groups of land holding

\begin{tabular}{|c|c|c|c|c|}
\hline Year & Small & Medium & Large & Overall \\
\hline \multirow{2}{*}{ I } & 112465 & 115407 & 116108 & 114466 \\
& $(45.08)$ & $(45.01)$ & $(44.93)$ & $(45.01)$ \\
\hline \multirow{2}{*}{ II } & 41568 & 42829 & 43224 & 42451 \\
& $(16.66)$ & $(16.70)$ & $(16.73)$ & $(16.69)$ \\
\hline \multirow{2}{*}{ III } & 44009 & 45516 & 45890 & 45038 \\
& $(17.65)$ & $(17.75)$ & $(17.76)$ & $(17.72)$ \\
\hline \multirow{2}{*}{ IV } & 51427 & 52669 & 53184 & 52330 \\
& $(20.61)$ & $(20.54)$ & $(20.58)$ & $(20.58)$ \\
\hline \multirow{2}{*}{ Total } & 249469 & 256421 & 258406 & 254285 \\
& $(100.00)$ & $(100.00)$ & $(100.00)$ & $(100.00)$ \\
\hline
\end{tabular}

Note: Cost of pond excluding from establishment 100 per cent assistance is provided under Mission for Integrated Development of Horticulture (MIDH) (Govt. of India) 
Table.3 Operational cost of kinnow orchard on different size group of land holding

\begin{tabular}{|c|l|c|c|c|c|}
\hline Sr. No. & \multicolumn{1}{|c}{ Particulars } & Small & Medium & Large & Overall \\
\hline 1 & Manures and fertilizers & 14520 & 14960 & 16672 & 15248 \\
& & $(38.11)$ & $(38.40)$ & $(39.31)$ & $(38.55)$ \\
\hline 2 & Intercultural operation and hoeing & 7665 & 7765 & 7963 & 7779 \\
& & $(20.12)$ & $(19.93)$ & $(18.78)$ & $(19.67)$ \\
\hline 3 & Irrigation and drip maintenance & 2456 & 2545 & 2786 & 2575 \\
& & $(6.45)$ & $(6.53)$ & $(6.57)$ & $(6.51)$ \\
\hline 4 & Pruning and cutting & 4125 & 4256 & 4524 & 4277 \\
& & $(10.83)$ & $(10.94)$ & $(10.67)$ & $(10.81)$ \\
\hline 5 & Insecticides and fungicides & 6254 & 6242 & 6663 & 6359 \\
& & $(16.40)$ & $(16.02)$ & $(15.71)$ & $(16.08)$ \\
\hline 6 & Replacement cost & 925 & 956 & 1237 & 1019 \\
& & $(2.43)$ & $(2.45)$ & $(2.92)$ & $(2.58)$ \\
\hline 7 & Watch and ward & 2156 & 2234 & 2563 & 2292 \\
& & $(5.66)$ & $(5.73)$ & $(6.04)$ & $(5.80)$ \\
\hline Total & & $\mathbf{3 8 1 0 1}$ & $\mathbf{3 8 9 5 8}$ & $\mathbf{4 2 4 0 8}$ & $\mathbf{3 9 5 4 9}$ \\
& & $\mathbf{( 1 0 0 . 0 0 )}$ & $\mathbf{( 1 0 0 . 0 0 )}$ & $(\mathbf{1 0 0 . 0 0})$ & $(\mathbf{1 0 0 . 0 0})$ \\
\hline
\end{tabular}

Table.4 Cost and returns of kinnow orchard on different size group of land holding

\begin{tabular}{|c|l|r|r|r|r|}
\hline \multicolumn{1}{|c}{ Particulars } & Small & Medium & Large & Overall \\
\hline Sr. No. & Rs.ha) \\
\hline 1 & Land rent & 32689 & 32710 & 32913 & 32756 \\
\hline 2 & Amortized fixed cost & 50677 & 51052 & 51141 & 50932 \\
\hline 3 & Operational cost & 38101 & 38958 & 42408 & 39549 \\
\hline 4 & Expected depreciation on fixed investment @ 4\% & 4499 & 4616 & 4644 & 4578 \\
\hline 5 & Interest on operational cost @ 12\% per annum & 4572 & 4675 & 5089 & 4746 \\
\hline 6 & Total cost (1 to 5) & 130538 & 132011 & 136195 & 132562 \\
\hline 7 & Production (qt) & 207 & 217 & 224 & 215 \\
\hline 8 & Gross returns & 248400 & 260400 & 268800 & 258040 \\
\hline 9 & Net returns from kinnow & 117862 & 128389 & 132605 & 125478 \\
\hline
\end{tabular}

Table.5 Economic viability of kinnow orchard on different size groups of land holding

\begin{tabular}{|l|c|c|c|c|}
\hline Measures of investment worth & \multicolumn{4}{|c|}{ Size of orchards (n=60) } \\
\hline Size of land holding & 0.01 to 2.00 ha & 2.01 to 4.00 ha & Above 4.00 ha & Overall \\
\hline Payback period (years) & 7.5 & 7.8 & 7.2 & 7.6 \\
\hline Net present value Rs.) & 238399 & 266341 & 267107 & 261258 \\
\hline At discount rate of 12\% & 14.57 & 15.56 & 16.61 & 15.57 \\
\hline Internal rate of return (\%) & 2.11 & 2.24 & 2.14 & 2.19 \\
\hline Benefit-cost ratio
\end{tabular}


Table.6 Channel-wise marketing cost and price spread in disposal of Kinnow produce

\begin{tabular}{|c|c|c|c|c|c|}
\hline & & & & \multicolumn{2}{|c|}{ (Rs./q) } \\
\hline Sr. No. & Functionary & Channel-I & Channel-II & Channel-III & Channel-IV \\
\hline 1 & $\begin{array}{l}\text { Net Price received by producer/purchase Price of pre harvest } \\
\text { contractor }\end{array}$ & $1120(51.28)$ & $1120(58.95)$ & $1195.83(63.85)$ & $1215.61(82.21)$ \\
\hline 2 & Cost incurred by the pre-harvest contractor & $258.02(11.81)$ & 258.02(13.58) & $270.17(14.42)$ & $252.39(17.19)$ \\
\hline 3 & Net margins of pre-harvest contractor & $172.98(7.92)$ & $106.98(5.63)$ & -- & - \\
\hline 4 & $\begin{array}{l}\text { Sale price of pre-harvest contractor/purchase price of } \\
\text { wholesaler }\end{array}$ & 1551(71.02) & $1485(78.16)$ & $1466(78.27)$ & - \\
\hline 5 & Cost incurred by the wholesaler & 273.31(12.51) & & & \\
\hline 6 & Net margin of wholesaler & $96.69(4.43)$ & - & - & - \\
\hline 7 & Sale price of wholesaler/purchase price of retailer & 1921(87.96) & - & - & - \\
\hline 8 & Cost incurred by the retailer & $129.25(5.92)$ & $262.90(13.84)$ & $262.31(14.00)$ & - \\
\hline 9 & Net margin of retailer & $133.75(6.12)$ & $152.10(8.01)$ & $144.69(7.73)$ & - \\
\hline 10 & Sale price of retailer/purchase price of consumer & $2184(100.00)$ & $1900(100.00)$ & $1873(100.00)$ & $1468(100.00)$ \\
\hline
\end{tabular}

Note: Figures in parentheses are the percentage to the consumer's price

Table.7 Marketing efficiency of different channels involved in disposal of produce

\begin{tabular}{|l|c|c|c|c|}
\hline \multicolumn{1}{|c|}{ Particulars } & Channel-I & Channel-II & Channel-III & Channel-IV \\
\hline Net price received by producer(Rs./q) & 1120 & 1120 & 1195.83 & 1215.61 \\
\hline Marketing margin (Rs./q) & 403.42 & 259.08 & 144.69 & 0.00 \\
\hline Marketing cost (Rs./q) & 660.58 & 520.92 & 532.48 & 252.39 \\
\hline Marketing efficiency & 1.05 & 1.44 & 1.77 & 4.82 \\
\hline
\end{tabular}

The NPV varied from small (Rs. 238399) to large orchards (Rs.267107), depending upon the size of orchards which indicated that NPV was highest in large orchard and lowest in small orchard.

The IRR ranging from 14.57 per cent in small orchards to 16.61 per cent in large orchards indicating that kinnow cultivation was a profitable enterprise. The average rate of return per year for the whole period of the orchard will be 14.57 per cent for small, 15.56 per cent for medium and 16.61 per cent for large orchards. The B: $\mathrm{C}$ ratio calculated for small, medium, large and overall orchards was $2.11,2.24,2.14$ and 2.19 respectively, indicating that the medium orchardist much better than others as returns per rupee invested was highest. The pay-back period of kinnow orchard was in the range of 7.2 years to 7.8 years. These findings are in close conformity with the results of Gangwar and Singh (1998).

\section{Marketing channels}

The following four major marketing channels were identified in the study area in disposal of kinnow depicted as under.

The detailed cost of marketing and price spread in disposal of kinnow are given in Table 6, shows that the channel-I also involved a marketing cost on per quintal basis pre-harvest contractor, wholesaler and retailer of (Rs. 258.02, 273.31 and 129.25) respectively. Channel -II and III involved almost same marketing cost i.e. wholesaler and retailer of channel -I (Rs 258.02 and 262.90/q) and channel -III (Rs. 270.17 and Rs. 262.31). In channel-IV, the producer had borne the whole marketing cost Rs. 252.39) as there was no intermediary in this channel and producer sold the produce directly to the consumer. The results of the price spread of kinnow under different marketing channels in the study area indicated that producers' share 
in consumers' rupee was highest in channelIV $(82.21 \%)$, followed by channel-III $(63.85 \%)$, channel-II $(58.95 \%)$ and channel-I $(51.28 \%)$, which revealed that direct sale in the local market provided a higher share to producer in the price paid by consumers'. In this channel (IV), both producers and consumers gained because the net price received by producers was highest and price paid by the consumer was lowest.

According to Table 7, maximum marketing efficiency (4.82) was observed when farmer sold his produce directly to consumer. The marketing efficiency where intermediary were involved was lower in all modes of marketing. The channel wise marketing efficiency for channel I, II, III was 1.05, 1.44 and 1.77, respectively. These results are in conformity with those of Bhat et al., (2011). Further marketing loss was minimum in channel-IV because loss due to perish ability, handling and transportation was almost negligible. The producer got maximum benefits in channel-IV; therefore this channel should be followed to accrue more benefits to producer; although this channel has its own limitations.

No doubt investment in kinnow orchards is a profitable enterprise for the orchardists. The overall per hectare establishment cost in first year and total establishment cost (4 years) of kinnow plantation has been worked out to be Rs. 399466/ha and 254285/ha respectively. The returns from kinnow orchards have been found as Rs. 125478 ha/year. The IRR, NPV, $\mathrm{B}$ : $\mathrm{C}$ ratio and payback period of kinnow worked out in the range of 14.57 to 16.61 per cent, Rs. 238399 to Rs. $267107,2.11$ to 2.24 and 7.2 to 7.8 , respectively, depending on the size of the orchards.

The price spread in marketing of kinnow in study area indicated that producers' share $(82.21 \%)$ in consumers' rupee was maximum when the produce sold fruits directly to consumer. Price spread analysis also revealed that different market intermediaries are the major beneficiaries in the all prevalent marketing channels. However, the marketing efficiency has been found high in channel- IV (4.82), followed by channel-III (1.77), channel- II (1.44) and channel-I (1.05) where intermediaries are the part of chain. No doubt investment in kinnow orchard is a profitable.

The cultivation of fruit crops like kinnow is one of the options for manifold increase in farm income. The cultivation of kinnow should be advocated among farmers by providing timely information pertaining to crop production and protection technologies. Farmers should be encouraged for cultivation of fruit crops by incentivizing them through implementation of crop development programmes and arrangement for disposal of produce at remunerative prices. The adequate scientific storage for longer shelf life of fruits and processing facilities may also further increase in value addition and higher returns to growers.

\section{References}

Acharya, S. S. and Aggarwal, N. L. (2001). Agricultural Marketing in India. Oxford \& IBH Publishing Company, New Delhi.

Anonymous (2015). Agricultural \& Processed Food Products Export Development Authority, Ministry of Commerce \& Industry, Government of India.

Banerjee, G. D. (2009). Poised for a golden revolution. Times Agriculture Journal, 01 April.

Bhat, A., Kachroo, J. and Kachroo, D.(2011) Economic appraisal of kinnow Production and its marketing under North- Western Himalayan Region of Jammu. Agricultural Economics Research Review, 24(2): 283-290. 
Gangwar, L. S. and Singh, S. (1998). Economic evaluation of Nagpur mandarin cultivation in Vidarbha region of Maharashtra. Indian Journal of Agricultural Economics. 53(4): 648653.

Gangwar, L. S., Ilyas, S. M., Singh, D. and Kumar, S. (2005). An economic evaluation of kinnow mandarin cultivation in Punjab. Agricultural
Economics Research Review. 18(1): 7180.

Sudha, M. and Reddy, Y. V. R. (1988). Economics of sweet orange cultivation. Indian Horticulture. 33(3): 24-25.

Thakur, D. S., Saibabu, M. V. S. and Sharma, K. D. (1986). Economics of kinnow cultivation in Himachal Pradesh. Himachal Journal of Agricultural Research. 12(1): 47-51.

\section{How to cite this article:}

Nirmal Kumar, Anju Duhan, Jitender Bhatia and Vinod Malik. 2017. Economic Appraisal of Kinnow Production and its Marketing in Sirsa District of Haryana. Int.J.Curr.Microbiol.App.Sci. 6(11): 4045-4053. doi: https://doi.org/10.20546/ijcmas.2017.611.473 